\title{
Tren Berhijab di Kalangan Anak Muda: Studi Komparatif pada Siswi SMA/MA/SMK di Pekanbaru
}

\author{
Euis Karmila \\ Fakultas Dakwah dan Komunikasi \\ Universitas Islam Negeri Sultan Syarif Kasim Riau, Indonesia \\ euiskarmila423@gmail.com
}

\begin{abstract}
This paper analyzes the use of hijab which is a trend now among teenagers in high school. This article will explain the differences between public schools and Islamic based schools. This study is important to see how the role of hijab trends in schools is used by students. Specifically, this article will address the following questions. Why girls hijab? What kind of model is used by schoolgirls like? What is the role of the school to educate students in the use of the hijab. Methodologically, the data for this article is sourced from field study research in several high school / vocational schools located in Pekanbaru. The author will ask several questions relating to the discussion that the writer will do. This article is analyzed with a number of literatures that are relevant to this research topic. The results of the study show that students who attend public schools attend schools that use the hijab. And in using hijab, it's very different. In the role of the school also differs between public schools and Islamic based schools. Starting in terms of regulations to how to educate students to use the hijab.
\end{abstract}

Kata Kunci: Hijab Trend, Hijra, Woman Student

\begin{abstract}
Abstrak
Tulisan ini menganalisis penggunaan hijab yang menjadi tren pada saat sekarang di kalangan para remaja yang masih sekolah tingkat menengah atas. Artikel ini akan menjelaskan perbedaan antara sekolah umum dengan sekolah yang berbasis Islam. Kajian ini penting dilakukan untuk melihat bagaimana peran tren hijab di sekolah yang dipakai oleh para siswi. Secara khusus, artikel ini akan membahas beberapa pertanyaan berikut. Kenapa para siswi hijab? Model yang biasa digunakan oleh siswi di sekolah itu seperti apa? Bagaimana peran pihak sekolah untuk mendidik siswi-siswi dalam penggunaan hijab. Secara metodologi, data artikel ini bersumber dari penelitian studi lapangan di beberapa sekolah SMA/SMK yang berada di Pekanbaru. Penulis akan mengajukan beberapa pertanyaan berkaitan dengan pembahasan yang akan penulis lakukan. Artikel ini dianalisis dengan sejumlah literatur yang relevan dengan topik penelitian ini. Hasil dari kajian tersebut menunjukkan bahwa para siswi yang bersekolah dalam sekolah umum dengan bersekolah di sekolah yang dalam menggunakan hijab. Serta dalam menggunakan hijabpun sangatlah berbeda. Dalam peranan pihak sekolah juga berbeda antara sekolah umum dengan sekolah berbasis Islam. Mulai dari segi peraturan hingga cara mendidik siswi untuk menggunakan hijab.
\end{abstract}


Kata Kunci: Tren Hijab, Hijrah, Siswi

\section{Pendahuluan}

Artikel ini membahas penggunaan hijab yang menjadi tren di kalangan anak muda pada saat sekarang ini. Pemakaian hijab di kalangan anak muda semakin banyak digunakan. Para anak muda menggunakan beraneka ragam model hijab yang tentunya akan menjadi sorotan terhadap Muslimah yang menggunakannya. Artikel in akan dikaitkan dengan anak muda muslim dan globalisasi.

Studi yang mengkaji tentang hijab pada remaja sudah banyak di tulis oleh peneliti. Dheajeng Thalita Riano ${ }^{1}$, Dheajeng meneliti sebuah fenomena yang ada pada zaman sekarang tentang buka tutup hijab yang dilakukan oleh para siswi. Dalam penelitian Dheajeng yang menjadi sasarannya yaitu para siswi yang masih bersekolah di sekolah umum. Hasil dari penelitiannya di sekolah tersebut hijab hanya digunakan sebagai pelengkap seragam saja. Para siswi saat mereka sudah tidak berada di sekolah, siswi tersebut melepas hijabnya dan tampil dengan berbeda.

Ummi Hani² meneliti tentang peran pentingnya motivasi terhadap perilaku sosial dalam menggunakan hijab. Fenomena yang terjadi para siswi memakai hijab pada saat di sekolah saja. Hal ini di sebabkan dari teman, tren yang ada pada saat sekarang ini. Bahkan ada siswi yang menggunakan hijab karena terpaksa.

Berbeda dengan yang dilakukan oleh Anisa Nurkhayati ${ }^{3}$. Anisa mengkaji dari aspek persepsi hal tersebut menimbulkan motivasi untuk menggunakan hijab. Fenomena hijab yang seharusnya menjadi penutup aurat bagi seorang Muslimah yang sudah akhir baligh ataupun sudah memasuki masa remaja. Hal tersebut menimbulkan motivasi untuk menggunakan hijab.

Studi-studi sebelumnya cenderung mengkaji tentang motivasi, persepsi, dan tindakan sosial. Artikel ini menampilkan hal yang berbeda dengan fokus membahas terhadap tren hijab remaja saat ini. Adanya penggunakan hijab yang beraneka ragam maka anak muda muslim akan terpengaruh dengan adanya perkembangana globalisasi. Dengan melakukan penelitian ini akan terlihat beraneka ragam tren mode hijab yang digunakan. Secara khusus, artikel ini mendiskusikan tiga

${ }^{1}$ Dheajeng Thalita Riano. Buka-Tutup Jilbab Di Kalangan Remaja (Studi Tentang Tindakan Sosial Pada Siswi Sma Dan Smk Di Surabaya). (Surabaya: Universitas Airlangga, 2017)

2 Ummi Hani. Pengaruh Motivasi Memakai Jilbab Terhadap Perilaku Sosial Siswi Smk Annuroniyah Sulang Rembang. (Semarang: UIN Walisongo, 2016)

3 Anisa Nurkhayati. Pengaruh Motivasi Memakai Jilbab Terhadap Perilaku Sosial Siswi Smk Annuroniyah Sulang Rembang. (Purwokerto: IAIN Purwokerto 2015) 
pertanyaan. Pertama, kenapa para siswi hijab? Kedua, model yang biasa digunakan oleh siswi di sekolah itu seperti apa? Ketiga, bagaimana peran pihak sekolah untuk mendidik siswi-siswi dalam penggunaan hijab.

Untuk menjawab pertanyaan-pertanyaan tersebut, artikel ini dibagi menjadi lima bagian. Pada bagian pertama, artikel ini menjelaskan latar belakang yang menjadi fokus kajian ini. Pada bagian kedua, artikel ini mengeksplorasi tentang tren perkembangan hijab yang digunakan. Bagian ketiga, artikel ini akan mendeskripsikan bagaimana hijab yang digunakan oleh siswi-siswi tingkat menengah atas. Bagian keempat, artikel ini akan menjelaskan pihak sekolah dalam mendidik terhadap penggunaan hijab siswi-siswi mereka. Bagian kelima, artikel ini akan menjelaskan tren hijab mana yang lebih disukai atau digunakan oleh siswisiswi tersebut.

Dalam artikel ini, penulis menempatkan hijab sebagai tren di kalangan anak muda yang masih sekolah di tingkat menengah atas, bagaimana mereka menggunakan hijab tersebut. Penulis akan memfokuskan kajian ini melalui beberapa institusi pendidikan tingkat menengah atas seperti SMK Taruna Satria Pekanbaru, SMA Teknologi Pekanbaru, MA Darul Hikmah, dan SMK IT Al-Izhar.

Dalam hal ini peneliti ingin melihat dan menganalisis perbandingan atau studi komparatif dari sekolah yang berbasis Islam dengan sekolah yang tidak berbasis Islam. Penelitian ini penting dilakukan untuk melihat tren hijab di kalangan siswi di tingkat SMA/SMK/MA yang ada di Pekanbaru.

\section{Metode Penelitian}

Secara metodologi, data artikel ini bersumber dari penelitian studi lapangan di beberapa sekolah SMA/SMK yang berada di Pekanbaru. Penulis mengajukan beberapa pertanyaan berkaitan dengan pembahasan yang penulis lakukan. Kemudian penulis melakukan wawancara kepada beberapa siswi dan guru agama sekolah tersebut sebagai data pendukung artikel ini dan juga menyebarkan kuesioner kepada siswi-siswi yang ada di SMA/SMK/MA yang ada di Pekanbaru. Terakhir, artikel ini dianalisis dengan sejumlah literatur yang relevan dengan topik penelitian ini.

\section{Hasil Penelitian dan Pembahasan}




\section{Tren Hijab}

Istilah hijab, pada awalnya tidak dikenal di tengah kalangan masyarakat. Umumnya masyarakat lebih mengenal kata jilbab daripada hijab. Istilah hijab untuk menyebutkan pakaian penutup aurat Muslimah yang lebih dahulu digunakan di negara Barat. Sementara di Indonesia penggunaan hijab semakin popular dengan desain yang beragam. Apalagi ketika tak lama setelahnya, lahirlah komunitas Muslimah pengguna hijab mode bernama Hijabers Community. ${ }^{4}$

Hijab dimaknai bukan hanya sebagai penutup aurat saja, tetapi juga sebagai simbol kesalehan yang dinilai sebagai menyempurnakan rukun keimanannya. Hijab kini sudah menjadi bagian dari sebuah busana. Hijab menjadi sebuah tanda yang menunjukkan setiap penggunaan yang dikenakan oleh individu tersebut menjadi sebuah fashion atau ciri khas individu tersebut. Hal ini tentu menjadi menarik dengan adanya penggunaan hijab tersebut tentu akan menjadi tren dengan pemakaian hijab yang bervariasi. Fenomena hijab ini tentu bias dikaitkan dengan adanya perkembangan globalisasi akan menjadi tren pada kalangan anak muda yang menggunakan. Terlebih lagi hijab ini dipakai oleh semua kalangan ${ }^{5}$

Tren hijab ini sudah diminati kaum perempuan beberapa tahun terakhir, mengingat hijab digunakan untuk menutupi aurat perempuan. Seiring perkembangan zaman di era modern ini, semakin banyak hijab yang beragam tipenya dan model yang unik serta warna dengan variasi sesuai konteks sekarang. Sehingga membuat hijab semakin banyak diminati sebagai gaya hidup.

Hijab yang dikaji sebagai sebuah fenomena, dari segala yang terlihat dan dapat dirasakan. Femomena hijab tersebut akan menjadi sebuah ciri khas. ${ }^{6}$ Oleh sebab itu hijab dalam penelitian ini tidak hanya dikaji sebagai sebuah objek benda, namun juga sebagai sebuah nilai, sebuah makna, hingga pada kelanjutannya adalah sebagai sebuah 'tanda'. Hijab tidak lagi semata sebuah benda bernilai guna yang merujuk pada pakaian penutup aurat wanita, melainkan juga sebagai sebuah tanda atau kode tentang kesalehan, ketaatan, kerendahan hati, sekaligus modern, kekinian, dan juga berkelas sosial.

Hijab bukan berbicara soal religiusitas, melainkan juga menjadi sebuah tren mode. Bagaimana hijab mengalami pergeseran makna pada saat sekarang ini, akan

${ }^{4}$ Tourmalina Tri Nugrahenny. "Menyingkap Mekanisme Tanda Di Balik Hiperrealitas Tren Hijab: Analisis Semiotika Pada Fenomena Tren Hijab". Jurnal Komunikasi Indonesia Volume V, Nomor 1. 2016, 16.

${ }^{5}$ Elisabeth Raleigh. Busana Muslim dan Kebudayaan Populer di Indonesia: Pengaruh dan Persepsi. Karya non Publikasi (Malang: tp., 2004), 14.

${ }^{6}$ A Van Zoest. Semiotika : Tentang Tanda, Cara Kerjanya Dan Apa Yang Kita Lakukan Dengannya. (Jakarta : Yayasan Sumber Agung, 1993), 19. 
dikaji dengan melihat mekanisme tanda yang berlangsung di balik pemakaian tren hijab tersebut. Hijab yang menjadi ciri khas tersebut tentu akan banyak peminatnya untuk menggunakannya. Atau sebaliknya, bagaimana mekanisme tanda, hingga hijab yang tadinya hanya sebagai objek benda bernilai guna, menjadi tren yang kemudian menjadikannya sebagai komoditas mode yang bernilai tanda. Dalam pemikiran Jean Baudrillard sebagai teori utama, yakni tentang masyarakat di era modren. Dasar-dasar pemikiran yang akan digunakan dalam penelitian ini berdasarkan pada karya Jean baudrillard, diantaranya Communications, Consumer Society dan Simmulations.

Indonesia sebagai Negara dengan penduduk muslim terbesar dengan BPD (Produk Domestic Bruto) tertinggi dari negara muslim lainnya hal ini dikarenakan konsumen Indonesia yang semakin meningkat tajam. Sementara berdasarkan data Biro Pusat Statistik (2010), kenaikan penduduk kelas menengah (berpenghasilan per hari US\$2-20) ini mencapai sekitar 8-9 juta penduduk per tahun.. ${ }^{7}$ Kelompok ini memiliki discretionary income (pendapatan menganggur) sekitar 1/3 dari keseluruhan pendapatan. Dalam hal fashion Muslimah, Indonesia juga menunjukkan antusiasme yang jauh lebih tinggi dibanding negara lain. Ketika Gross National Product (GNP) per kapita meningkat di Indonesia, terciptalah satu kelas masyarakat menengah baru, yang dapat menentukan gaya hidupnya secara bebas sesuai dengan pilihannya. $^{8}$

Dengan mengikuti perkembangan zaman, kehidupan masyarakat Indonesia juga secara siginifikan menjadi religius. ${ }^{9}$ Semakin pesatnya perkembangan industri hijab diikuti semakin besarnya target pasar, maka produk busana Muslimah ini pun makin masif dan mulai menjadi tren fashion di kalangan masyarakat. Beragam kreasi dalam industri hijab pun terus dilakukan, agar produk mampu bertahan sebagai komoditas, sehingga terus dikonsumsi pasar. Ketika masuk dalam industri, hijab tidak lagi sekedar dimaknai sebagai sebuah perintah agama "semata", melainkan terus berkembang dan masuk dalam ranah budaya.

Oleh karenanya ketika menjadi komoditas, maka hijab menjadi sistem tanda yang dimiliki. ${ }^{10}$ Simulasi yang berlangsung terus menerus ini, pada akhirnya

7 Yuswohadi \& Gani. Marketing To The Middle Class Muslimah. (Jakarta : Pt Gramedia Pustaka Utama 2015), 5.

${ }^{8}$ Piliang. Dunia Yang Dilipat, Tamasya Melampaui Batas-Batas Kebudayaan. Edisi Tiga. (Bandung : Matahari, 2011), 251.

${ }_{9}$ Yuswohadi \& Gani. 8 Wajah Kelas Menengah. (Jakarta : Pt Gramedia Pustaka Utama, 2015), 6.

${ }^{10} \mathrm{~J}$ Baudrillard. The Consumer Society: Myths And Structures (Published In Association With Theory, Culture \& Society). (London: Sage Publications, 1970). 
membentuk hiperreality atau yang disebut dengan ketidakmampuan kesadaran manusia untuk membedakan kenyataan dengan fantasi. ${ }^{11}$ Demikian halnya pula dengan hijab, yang model-model barunya bahkan menciptakan yang bermakna yang relatif dan variatif, bergantung pada desainer yang menciptakannya.

Di satu sisi, memakai hijab memberikan 'nilai lebih' bagi pemakainya. Makna hijab menjadi relatif, menjadi elastis bergantung pada nilai tanda yang dilekatkan (atau melekat) padanya. Sebagai tanda dan simbol, makna hijab dapat secara bebas di produksi. Jika di Indonesia sebelum tahun 1990 hijab memberi makna perlawanan bahkan fanatisme, maka tidak demikian halnya dengan hijab di era milenial. Hijab telah populer, hijab adalah popularitas karena ia dikenakan orang-orang populer sebagai modelnya. Hijab pada saat ini justru menjadi nilai yang membuat kekinian, sekaligus menambah kesalehan seseorang. ${ }^{12}$

Pada masa kesadaran berhijab Muslimah masih rendah, hijab hanya memenuhi ruang pasar pada momen tertentu saja, seperti Hari Raya atau Bulan Suci Ramadhan. Sementara ketika hijab menjadi populer dengan peran para selebriti yang berhijrah, adanya peningkatan kelas menengah masyarakat yang signifikan, serta adanya gejala neospiritualisme ${ }^{13}$ maka pemakai hijab pun melonjak, pelonjakan inilah yang kemudian dijadikan pasar bagi para produsen. Dari masa ke masa, agar terus dikonsumsi, maka hijab dijadikan objek yang memiliki sebuah ciri khas. ${ }^{14}$ Sementara agar terus memiliki nilai tanda, maka diperlukan adanya logika diferensiasi atau disebut sebagai logika tanda atau logika konsumsi, sebagai bagian penting untuk membedakan logika atas produk konsumsi. Hijab telah menyamai mode baju pada umumnya. Hijab juga banyak digunakan oleh para selebriti bahkan banyak juga yang membuat brand hijab sendiri. Dengan seperti itu seseorang yang menggunakan hijab tersebut tentu akan merasa sudah sama dengan selebriti tersebut. Tak heran ketika para selebriti itu merilis label fashion, Muslimah pun berbondong-bondong membelinya. ${ }^{15}$

Sebagai seorang Muslimah dalam agama Islam, berhijab dianjurkan untuk meutupi auratnya dan menjaga dirinya. Pada saat istilah hijab ini popular, hijab

11 J Baudrillard. Simulations.Translated By Paul Foss, Paul Patton And Phillip Beitchman. (Cambridge: Cambridge University Press, 1983), 2.

12 Barnard, M. Fashion Sebagai Komunikasi. Penterjemah Idi Subandy Ibrahim. (Yogyakarta : Jalasutra, 2011)., Xii.

13 Piliang, , Y. A. Dunia Yang Dilipat, Tamasya Melampaui Batas-Batas Kebudayaan. Edisi Tiga. (Bandung : Matahari ,2011), 252.

14 Baudrillard, J. Simulations. Translated By Paul Foss, Paul Patton And Phillip Beitchman. (Cambridge: Cambridge University Press, 1983), 66.

15 Baudrillard, J. The Consumer Society: Myths And Structures (Published In Association With Theory, Culture \& Society). (London: Sage Publications, 1970), 29. 
dikenal hanya sebagai penutup rambut dan kepala saja. Dalam kehidupan seharihari, hijab sering identik dengan istilah kerudung. Hal ini juga menyebabkan berbagai sudut pandang dan konsep dalam pemakaian hijab. Hijab yang digunakan hanya sebatas menutupi bagaian kepala saja, namun tidak memperhatikan bagian yang lainnya. ${ }^{16}$

Cara berbusana semacam inilah yang kemudian mengundang pandangan negatif masyarakat dan sempat memunculkan kontroversi. Hal ini tentu saja mengimplikasikan penyimpangan atas konsep hijab sebagai pakaian yang bertujuan untuk menutupi aurat. Bahkan ada juga yang memaknai hijab sebagai pembatas agar tidak saling bertatap wajab langsung antara wanita muslimah dan laki-laki dalam satu ruangan, atau di dalam masjid. Di Indonesia hijab dianggap hanya sebatas menutupi bagian kepala. Namun dalam Islam istilah hijab ini tidak hanya sebatas untuk menutupi aurat saja, tetapi juga menutupi seluruh anggota badan dengan mengikuti tata cara berpakaian sebagai seorang muslimah yang syar'i.

Dalam ajaran Islam, memang tidak ada aturan khusus tentang gaya atau model busana, namun tetap harus menutupi bagian dari aurat wanita. Hal ini juga bisa mengandalkan kreativitas mereka untuk berinovasi dan bereksplorasi untuk menciptakan kreasi-kreasi busana yang sesuai dengan syariat, yakni dapat menutupi seluruh anggota tubuhnya. Berkaitan dengan hal ini, pemakaian hijab tidak hanya dipakai hanya untuk mempercantik diri saja, tetapi juga dilakukan sebagai salah satu bentuk rasa syukur kepada Allah. Para perancang busana dalam hal ini juga memperhatikan aturan-aturan agar tidak menyimpang untuk dikenakan oleh wanita muslimah. ${ }^{17}$

Terlepas dari segala pandangan masyarakat dan pengertiannya, hijab dan pakaian yang menutupi sebagian besar tubuh wanita, diakui atau tidak adalah bagian dari tradisi dan ajaran agama. Hijab telah menjadi simbol kebaikan dan ketaatan terhadap sebuah keyakinan. Hijab yang digunakan mennjadi sebuah identitas bagi para pemakainya, seperti sebagai tanda kebaikan, kesopanan bahkan kesalehan.

Memakai jilbab atau hijab memang menjadi kewajiban setiap Muslimah, tetapi sampai saat ini banyak perempuan-perempuan yang masih banyak yang belum menggunakannya. Masih banyak beragam alasan yang ditemukan antara lain

${ }^{16}$ Khairun Nisa \& Rudianto. "Trend Fashion Hijab Terhadap Konsep Diri Hijabers Komunitas Hijab Medan". Jurnal Interaksi Vol 1, No 1 (2017), 112.

${ }^{17}$ Nisa \& Rudianto. “Trend Fashion Hijab Terhadap Konsep Diri Hijabers Komunitas Hijab Medan”, 114. 
hijab dianggap sebagai penghambat aktivitas dan kurangnya bias bergaya jika menggunakannya. Hal ini dikarenakan di beberapa negara mayoritas muslim yang lain hijab tidak dibuat beraneka ragam bentuk yang membuat hijab menjadi tidak banyak pilihan. Sehingga seorang perempuan yang pada awalnya tidak berhijab lalu memutuskan untuk mengenakan hijab menjadi salah satu tanda bahwa dirinya telah mengalami transformasi menjadi manusia yang lebih baik. ${ }^{18}$

Seorang wanita yang telah memasuki masa remaja dan telah memasuki jenjang pendidikan SMA atau sederajat adalah sebagai masa peralihan, perubahan dari masa remaja menuju masa dewasa. Karena secara Hukum dan Perundangundangan seorang remaja yang telah memasuki usia 17 atau 18 tahun sudah dianggap dewasa dan di mata hukum dapat dijatuhi hukuman ketika melalukan tindakan pelanggaran terhadap peraturan Perundang-undangan. ${ }^{19}$ Dengan demikian anak diusahakan tepat dalam memilih teman bergaul baik di lingkungan rumah maupun teman di lingkungan sekolah. Orang tua selaku penanggung jawab pendidikan anak di rumah harus mampu menanamkan pendidikan dasar keagamaan yang kuat, sehingga anak akan tumbuh menjadi anak yang memiliki kepribadian yang kuat pula, karena diharapkan anak mampu membawa dirinya dalam pergaulan yang baik. Salah satu alternatif yang bias digunakan oleh orang tua yaitu dengan mengajarkan anak dari kecil untuk menggunakan hijab. Hal ini bias menjadi penanaman karakter sejak kecil.

Perkembangan remaja menuju kedewasaan tidaklah selalu berjalan lancar, akan tetapi banyak mengalami rintangan. Besar kecilnya rintangan itu ditentukan oleh faktor-faktor yang mempengaruhi anak semasa kecil di lingkungan rumah tangga dan lingkungan masyarakat dimasa anak itu hidup dan berkembang. ${ }^{20}$ Seiring dengan perkembangan pada usia remaja, remaja sering mencari teman yang cocok bagi dirinya. Salah sedikit saja dalam memilih teman (orang yang berperilaku negatif/ nakal) dapat membawa dirinya ke dalam pergaulan yang negatif dan masuk dalam masalah kenakalan remaja. Maka dari itu, peran guru dan orang tua dalam pemilihan teman untuk anak sangat penting.

Sekolah merupakan salah satu lembaga yang bertanggung jawab atas pendidikan anak selain dari orang tua dan masyarakat. Diharapkan lembaga sekolah dapat menanamkan pendidikan budi pekerti yang mampu membentuk anak menjadi manusia yang bertanggung jawab dikemudian hari. Pada saat ini,

${ }^{18}$ Nisa \& Rudianto. “Trend Fashion Hijab Terhadap Konsep Diri Hijabers Komunitas Hijab Medan", 115.

${ }^{19}$ Zakiah Daradjat. Remaja Harapan Dan Tantangan. (Jakata: CV. Ruhama 1999), 9-10.

${ }^{20}$ S Willis Sofyan. Probleman Remaja Dan Pemecahannya. (Bandung: Aksara, 1994), 8. 
hijab sudah banyak digunakan oleh semua kalangan dalam kehidupan sehari-hari. Mulai dari lingkungan instansi pendidikan, dan kantor sebagai seragam seragam dan isentitas bagi seorang wanita muslimah. Bagi siswi di sekolah-sekolah baik ditingkat dasar maupun ditingkat lanjutan, kerudung sudah menjadi pakaian yang umum bahkan ada yang sudah menjadi sebuah keharusan dan tercantum dalam tata tertib berpakaian. Namun apakah penggunaan kerudung di dunia pendidikan menjamin perilaku pemakainya untuk berperilaku baik, baik secara umum maupun dalam hal keagamaan khususnya, ataupun perilaku hubungan dengan lawan jenis. Berpakaian dan cara berinteraksi dengan lingkungan yang dilakukan oleh seorang anak dapat mencerminkan kepribadian dan memungkinkan perilaku tersebut menjadi sebuah budaya yang melekat pada diri anak tersebut dan terbawa sampai dewasa. Apabila budaya itu suatu kebaikan, maka anak tersebut akan menjadi anak yang baik menurut lingkungannya, begitu juga apabila budaya beragama anak baik maka baik pula anak tersebut secara agama. ${ }^{21}$

Pada umumnya yang memberlakukan peraturan menggunakan hijab pada siswinya adalah di Madrasah Aliyah dan Madrasah Tsanawiyah, namun semakin berkembangnya tren model hijab yang berkembang pada masa kini, bukan hanya di Madrasah Aliyah saja yang memberlakukan peraturan tersebut. Melainkan di Sekolah Menengah Atas dan juga yang berbasis umum sudah mulai memberlakukan peraturan tersebut untuk siswi-siswi Muslimahnya (beragama Islam). ${ }^{22}$

Beberapa perbedaan antara sekolah umum dan sekolah yang berbasis islam antara lain yaitu dilihat dari sejarahnya. Sekolah umum mengadopsi dari system lembaga pendidikan modern dari Belanda secara keseluruhan. Berbeda dengan sekolah yang berbasis Islam mengadopsi dari substansi dan metodologi pendidikan modern. Namun penggunaan lembaga berbasis tradisional pendidikan sebagai basis utamanya. Sekolah umum berada dibawah naungan Departemen Pendidikan, sedangkan sekolah berbasis Islam dibawah naungan Departemen Agama. ${ }^{23}$

Tren hijab pada kalangan anak muda saat ini menjadi sebuah ciri khas yang membuat anak muda semakin percaya diri ketika menggunakan hijab tersebut.

${ }^{21}$ Shinta Nur Latifah Uswa. Hubungan Antara Kesadaran Menggunakan Jilbab Dengan Perilaku Beragama Siswi Muslimah SMA Negeri 1 Sigaluh Kabupaten Banjarnegara. (Purwokerto: Iain Purwokerto, 2017), 4.

${ }_{22}$ Uswa, Hubungan Antara Kesadaran Menggunakan Jilbab Dengan Perilaku Beragama Siswi Muslimah SMA Negeri 1 Sigaluh Kabupaten Banjarnegara, 5.

23 Muhammad Kholid Fathoni. Pendidikan Islam Dan Pendidikan Nasional, Paradigma Baru. (Jakarta: Departemen Agama RI, 2005), 71. 
Dengan berbagai macam bentuk hijab yang ditawarkan opeh para perancang hijab. Tentu membuat anak muda semakin tertarik untuk menggunakannya. Bentuk yang modis dan banyak juga pilihan warna yang membuat seseorang menggunakannya tentu akan terlihat lebih elegan dan menambah kepercayaan diri. Selain itu juga dengan perkembangan era globalisasi saat ini tentunya menjadi pendorong hijab menjadi tren pada saat sekarang ini. Hijab semakin tersebar luas bahkan sudah dipakai juga disemua kalangan. Bahkan dalam kehidupan sehari-hari juga hijab sudah digunakan.

\section{MA Darul Hikmah}

Pondok Pesantren Darul Hikmah atau lebih dikenal dengan Dar El Hikmah didirikan dibawah rintisan Yayasan Nur Iman Pekanbaru. Cita-cita berdirinya dikokohkan dengan adanya akte Notaris tanggal 12 September 1987 Nomor 43 oleh Notaris Tajib Raharjo, SH. Pondok Pesantren ini juga didirikan dengan motivasi pada keinginan untuk membina umat yang berbentuk sosial dan amaliyah guna mendidik generasi kita dengan ajaran Islam secara baik pula. Pendirian Pondok Pesantren ini dirintis semenjak tahun 1987 yang diawali dengan adanya waqaf sebidang tanah dari Bapak $H$. Abdullah yang terletak di jalan raya $H R$. Soebrantas / Jalan Manyar Sakti Km.12 Kelurahan Simpang Baru Kecamatan Tampan Kota Pekanbaru Provinsi Riau.

Adanya usaha pengurus, Yayasan Nur Iman Pekanbaru mencari tenaga pengajaran dan menghubungi beberapa pesantren yang ada di daerah maupun yang diluar daerah dengan bantuan Bapak Prof. Dr. H. Satria Efendi M. Zein (Alm) Dosen Pasca Sarjana Institut Agama Islam Negeri (IAIN) Syarif Hidayatullah Jakarta, maka dengan ini terwujudlah cita-cita untuk mendirikan Pondok Pesantren Dar El Hikmah Pekanbaru.

Saat ini pondok pesantren Dar El Hikmah telah memiliki asrama dua tingkat, workshop menjahit, pertukangan kayu dan peternakan unggas. Begitu pula kegiatan santrinya mereka telah memberikan andil besar dalam mengembangkan pengetahuan keagamaan masyarakat melalui pemberian pelajaran keagamaa dan pengajaran baca dan tulis Al-Qur'an. Dalam pengembangan sumber daya manusia, pondok pesantren memberikan kesempatan kepada para guru untuk menambah wawasan keilmuan. Mereka diperkenankan melanjutkan studi ke perguruan tinggi. Mereka juga mengutus para guru untuk mengikuti berbagai seminar dan penataran. Prestasi mereka dapat dibanggakan. Begitu pula dengan santrinya pernah menjuarai lomba pidat tingkat nasional yang diadakan Ikatan Pecinta Rethorika Indonesia (IPRI) di Jakarta. Dalam kegiatan kepramukaan, pondok pesantren Dar El Hikmah 
sudah cukup dikenal. Pada hampir setiap event, khususnya di daerah Riau, selalu menjadi yang terbaik. Bahkan pernah mengirimkan utusan ke Jambore Nasional dan Muhibah se-ASEAN. Di antara kekhususan pondok pesantren adalah dari segi penekanan pembelajaran pada bidang bahasa, akidah dan pendidikan agama. Khusus untuk bahasa yang diupayakan sekuat tenaga agar para santri dapat menguasai dua bahasa asing yaitu Bahasa Arab dan Bahasa Inggris. ${ }^{24}$

Visi: Menjadi lembaga pendidikan Islam yang berkualitas dalam pembinaan moral maupun intelektual bertaraf nasional pada tahun 2020.

Misi : Menyelenggarakan pendidikan formal dari tingkat dasar sampai tingkat perguruan tinggi berasis imtaq dan iptek. Menyelenggarakan bimbingan dan penyuluhan keagamaan kepada masyarakat..$^{25}$

Penulis menganalisis penggunaan hijab pada siswi Dar El Hikmah dengan melakukan wawancara terhadap guru agama dan siswi tentang penggunaan hijab tersebut.

Berdasarkan hasil wawancara dengan salah satu guru Fiqih bernama Ustad Bakri2 ${ }^{26}$ mengenai tren hijab yang ada di lingkungan Ponpes Dar El Hikmah. Ustad Bakri mengatakan : "Peraturan dalam pemakaian hijab itu sudah ada peraturannya, baik mengenai pemakaian berpakaian santriwan dan santriwati. Peraturan hijab di pondok berbeda dengan sekolah-sekolah umum lainnya. Yang namanya pondok mulai dari celana, baju dan dari yang bagian menutup aurat memiliki aturan tersendiri. Pihak sekolah melarang untuk menggunakan celana jenis jeans, ataupun yang ketat. Misalnya dalam penggunaan pakaian tidur juga ada aturannya mereka tidak diperbolehkan memakai keluar dari asrama dan hanya diperbolehkan di dalam asrama saja. Hijab yang digunakan adalah yang menutup aurat, rambut tidak terlihat ketika memakai hijab. Hijab yang digunakan adalah bermodel kan syar'i yang menutupi dada sampai menutupi pinggul sehingga lekuk bagian tubuh tidak terlihat. Karena sudah dari awal para siswi masuk dan sudah diterap kan peraturan-peraturan penggunaan dalam pakaian maka sejauh ini siswi belum ada melakukakan pelanggaran dalam pengggunaan berhijab. Jika terdapat siswi yang melanggar aturan pakaian akan dikenakan sanksi dan untuk pemakaian anak hijab pun jika tidak dipakai maka terdapat sanksi. Para siswi yang masuk mereka dari

${ }^{24} \mathrm{Http}: / /$ Www.Alkhoirot.Net/2011/10/Pondok-Pesantren-Darul-Hikmah-Ppdh.Html, Diakses Tanggal 15 Januari 2019.

${ }^{25}$ Maya Jumiati Yetri. Upaya Guru Meningkatkan Minat Belajar Santri Pada Mata Pelajaran Ekonomi Di Madrasah Aliyah Darel Hikmah Pekanbaru. Skripsi UIN Suska Riau 2013

26 Wawancara dengan Bakri, guru akidah akhlak di PPMA Darul Hikmah, Pekanbaru Pada 16 Januari 2019 
awal sudah mengenakan hijab jadi dalam aturan penggunaaan hijab dan pakaian yang baik pihak sekolah memberitahu bagaimana yang seharus nya di ajarkan dalam Islam mulai dari membawa mukena dan itu dilakukan oleh para santri pengurus OSDH (Organisasi Santri Darul Hikmah). Buku-buku yang dipakai dalam permasalahan fikih yang dipakai adalah Toha Putra, selain materi hijab materi yang diajarkan antara lain materi kepondokan dan materi-materi lainnya yang sangat mendukung sekali dalam menutup aurat."

Selain itu peneliti telah mewawancarai beberapa siswi yang ada di Ponpes Dar El Hikmah. Dilla Annisa ${ }^{27}$ mengungkapkan : "Hijab sebagai penutup aurat agar hijrah yang lebih baik model yang biasa digunakan seperti segitiga atau segi empat alasannya karna itu simple dan mudah digunakan. Dan tahu model hijab seperti itu dari teman dan internet, menggunakan hijab baik dirumah dan disekolah model nya beranekaragam tidak selalu sama temen yang berada dirumah dan disekolah menggunakan model hijab yang sama orang tua mewajibkan pake hijab tokoh hijab yang disukai Saritiuw yang merupakan youtuber hijab karena simple dan stylish."

\section{SMK Taruna Satria Pekanbaru}

SMK Taruna Satria Pekanbaru didirikan oleh Yayasan Amaliah merupakan lembaga pendidikan Menengah Kejuruan yang bebasis semi militer yang dibina oleh Kodim 0301 Pekanbaru. Bertujuan untuk mendidik anak bangsa menjadi calon pemimpin yang memiliki ilmu pengetahuan, keterampilan, berjiwa patriotisme dan ciinta tanah air. Lama pendidikan selama 3 tahun dengan tenaga pengajar berkualitas yang berasal dari perguruan tinggi terkemuka yaitu ITB, UGM, USU, UNP, UNRI, dan UIR. Yang terletak di Jl. Delima. No. 5 Panam7.

Visi : Menjadikan SMK Taruna Satria Pekanbaru sebagai sekolah kejuruan yang berdisiplin tinggi, unggul, maju, tangguh di wilayah sumatera pada tahun 2020.

Misi : Terciptanya tamatan SMK Taruna Satria Pekanbaru yang memiliki kepribadian taruna, kompeten dibidang ilmu pengetahuan dan teknologi. Siap pakai dan dibarengi dengan iman dan taqwa.

Hasil wawancara yang dilakukan peneliti kepada salah satu guru Agama Islam yaitu bapak Zulkifli. ${ }^{28}$ Ungkapnya :" Pihak sekolah dalam peraturan sementara pihak sekolah belum mewajibkan siswi untuk menggunakan hijab dan di

\footnotetext{
${ }^{27}$ Wawancara dengan Dilla Annisa, siswi kelas XII Jurusan IPS: PPMA Darul Hikmah, Pekanbaru Pada 16 Januari 2019

${ }^{28}$ Wawancara dengan Zulkifli, guru Agama Islam di PPMA Darul Hikmah, Pekanbaru pada 17 Januari 2019.
} 
sekolah juga terdapat siswi non Muslimah dan mereka tidak menggunakan hijab dan setiap hari Jum'at ataupun memperingati hari besar Islam. Siswi non Muslimah diperkenankan menggunakan hijab jika mereka mau. Kurikulum tentang hijab ada, terdapat tiga jam pelajaran, peraturan pemakaian hijab juga ada walaupun belum diwajibkan. Biasanya mereka memakai hijab didalam sekolah dan memakai hijab juga diluar sekolah dalam model penggunaan hijab yaitu hijab sorong atau yang langsung dipakai. Pihak sekolah terutama guru agama Islam menghimbau untuk para siswi menggunakan hijab baik didalam maupun diluar sekolah. Buku-buku agama yang dipakai yaitu Yudistira dan buku agama lainnya. Selain materi hijab terdapat beberapa materi agama lain seperti iman kepada malaikat hikmah zakat, haji, wakaf serta dakwah rasulullah."

Selain itu peneliti juga mewawancarai beberapa orang siswi. Safitri ${ }^{29}$ mengatakan : "Alasan memakai hijab karena itu merupakan kewajiban seorang Muslimah. Motivasinya karena melihat orang itu terlihat cantik dan kewajiban. Model hijab yang digunakan yang menutupi dada dan simple. Model hijab seperti yang digunakan dari orang tua dan temen-temen. Model hijab yang digunakan disekolah dan dirumah itu sama. Memakai hijab tidak hanya di sekolah saja tetapi di rumah juga. Orang tua mewajibkan pakai hijab. Temen bermain di rumah dan sekolah menggunaan hijab dengan model yang sama. Dalam memotivasi tementemen yang belum menggunakan hijab masih belum dilakukan. Tokoh hijab yang disukai yaitu ibu Halimah yang merupakan guru bahasa Inggris yang mengajar di sekolah tersebut karena terlihat cantik dan anggun."

\section{SMA Teknologi Pekanbaru}

SMA Teknologi Pekanbaru didirikan oleh yayasan dear teknologi hamid (YDTH). Jl. Kubang Raya No.KM 1.5, Tuah Karya, Tampan. Yayasan ini tidak hanya terdapat SMA saja namun ada juga SD dan SMP

Hasil wawancara yang dilakukan dengan salah satu guru Agama Islam yang bernama Bapak Salahudin ${ }^{30}$. Beliau mengatakan : “Sekolah mewajibkan siswi untuk menggunakan hijab dan di sekolah memiliki icon berupa sepanduk contoh penggunaan hijab yang benar saat berada di sekolah dan mereka tanpa ada paksaan dari awal sudah menggunakan hijab sejak saat masuk ke sekolah. Tidak terdapat

\footnotetext{
29 Wawancara dengan Safitri Zulyani, siswi kelas XII Jurusan Teknik Komputer Jaringan SMK Taruna Satria Pekanbaru pada 16 Januari 2019.

${ }^{30}$ Wawancara dengan Salahudin, guru Agama Islam di SMA Teknologi Pekanbaru pada 17 Januari 2019.
} 
kurikulum tentang hijab namun guru agama selalu menyinggung dan menyelipkan materi tentang penggunaan hijab disaat jam belajar misalnya dalam penyampaian rukun iman maka akan diselipkan materi tentang hijab dan menyampaikan ketika siswi mengenakan hijab maka akan sedikit menolong orang tua mereka dari siksaan api neraka. Model penggunaan hijab yang digunakan beraneka ragam bentuknya yang membuat mereka nyaman saat para siswi dalam memakainya seperti karna tidak ada standarisasi dalam penggunaan hijab dan tidak ada siswi yang melanggar aturan hijab. Karna sudah terdapat icon siswi yang berbusana Muslimah yang benar saat berada di sekolah. Maka pihak sekolah memotivasi para siswi untuk menggunakan hijab agar para siswi menggunakan hijab dengan semestinya. Selain materi hijab materi yang diajarkan seperti materi akhlak materi hari kiamat, sejarah nabi dan fikih."

Peneliti juga mewawancarai beberapa orang siswi, diantaranya adalah Putri ${ }^{31}$ mengatakan : "Menggunakan hijab untuk menutup aurat dan menghindari sinar matahari. Biasa menggunakan hijab langsung karena harganya lebih murah. Menurutnya munculnya hijab populer yaitu semakin banyaknya bentuk model hijab yang semakin beragam dan tentunya harga juga berbeda-beda sesuai model dan bahan yang digunakan. Hal ini memudahkan para pengguna memilih model mana yang ingin digunakan. Putri mengetahui model hijab seperti itu dari kakaknya karena melihat kakaknya terlihat cantik. Hijab yang dipakai di sekolah dan di rumah berbeda. Teman bermain di sekolah menggunakan model yang sama tetapi di rumah model yang berbeda. Orang tua putripun belum mewajibkan untuk menggunakan hijab. Tokoh yang disukai yaitu zaskia sungkar."

\section{SMK IT Al-Izhar School Pekanbaru}

SMK ini beralamat di Jl HR. Subrantas KM. 15 tepatnya di depan Universitas Islam Negeri Sultan Syarif Kasim (UIN Suska). Dengan banyaknya berdiri bank syariah maka pihak SMK tersebut berinisiatif untuk mendirikan SMK IT Al-Izhar School yang mempelajari jurusan Perbankan Syariah. Sekolah ini mempunyai bank mini syraiah yang bekerjasama dengan BR (Bank Riau Kepri Syariah), bank BNI syariah, bank Mandiri syariah, BMP Marwah dan lainnya. SMK ini berdiri pada tahun 2013 yang di resmikan oleh Bapak Walikota Firdaus, yang sudah menamatkan satu angkatan siswa yang berjumlahkan 8 orang. Saat ini sudah melanjutkan kejenjang pendidikan yang lebih tinggi. Jumlah siswa dari SMK tersebut adalah sebanyak 63 siswa. Yang mana kelas 1 berjumlah 23 orang, kelas 2 berjumlah

\footnotetext{
${ }^{31}$ Wawancara dengan Putri, siswi kelas XII IPS SMA Teknologi Pekanbaru pada 15 Januari 2019.
} 
34orang dan kelas 3 berjumlah 6 orang. Sedangkan kurikulum pembelajaran SMK ini memakai kurikulum KTSP.

Visi: Terwujudnya tenaga terampil siap pakai yang beriman, bertaqwa dan jujur di bidang perbankan syari'ah serta mampu bersaing dalam dunia usaha dan industri.

Misi : Menyelanggarakan pendidikan terampil dalam bidang perbankan syari'ah menggunakan teknologi informasi dan komunikasi. Mengembangkan iklim pembelajaran dan pelatihan yang berakar pada norma agama sehingga menghasilkan tamatan yang berakhlak mulia serta berbudi luhur. Dan menumbuhkan jiwa kreativitas, inovasi dan kewirausahaan kepada siswa sehingga dapat bersaing di dunia usaha dan industri. ${ }^{32}$

Hasil penelitian yang dilakukan oleh peneliti kepada Bapak Muhammad Saifudin ${ }^{33}$ yang merupakan salah satu guru Fikih, mengatakan : "Hijab merupakan peraturan agama Islam. Sekolah juga berbasis Islam dan siswi juga beragama Islam semua maka pihak sekolah mewajibkan siswi untuk berhijab materi tentang hijab ada disampaikan disaat kelas satu mengenai tata cara busana terfokus pada adat dalam berbusana terdapat 6 jam terdapat peraturan penggunaan hijab yaitu berhijab syar'i yang menutupi dada dan para siswi yang baru masuk sekolah akan diberikan masa sosialisasi selama 3 bulan untuk beradaptasi dalam berbusana syar'i dan selama ini. Selama masa itu siswa belum ada yang melanggar dan mereka sudah terbiasa menggunakan hijab yang syar'i. Penerbit buku yang dipakai yaitu Erlangga, Yudistira, dan buku buku agama lainnya yang menunjang pelajaran dan kitab fikih yang dipakai pada umumnya. Selain materi hijab materi agama yang diajarkan terdapat juga kajian setiap minggu mulai dari bab thaharah (bersuci), sholat, zakat, dan materi tentang keputrian yang membahas tentang aspek wanita."

Selain itu peneliti juga mewawancarai beberapa orang siswi. Rada ${ }^{34}$ mengatakan : "Memakai hijab karna itu suatu kewajiban dan motivasinya untuk orang tua ingin menyelamatkan ayah dari siksa api neraka dan menjaga iffah dan asas sebagai seorang wanita model hijab yang digunakan yaitiu syar'i yang menutup dada dan menutupi pinggul. Alasannya karena itu lebih menjaga serta sesuai dengan syariat Islam. tau model hijab itu awalnya dari perpustakaan dan

${ }^{32} \mathrm{Http}: / /$ Inlislite.Uinsuska.Ac.Id/Uploaded_Files/Temporary/Digitalcollection/Yzhlzjjmnddkotkzztviz dblnziymmm4m2fhnduzywqxnde0nzy0yq==.Pdf diakses pada 20 Maret 2020

${ }^{33}$ Wawancara dengan Muhammad Syaifudin, guru Fikih di SMK IT Al-Izhar Pekanbaru pada 16 Januari 2019.

${ }_{34}$ Wawancara dengan Rada, siswi kelas XII Perbankan Syariah SMK IT Al-Izhar Pekanbaru pada 16 Januari 2019. 
melihatnya bagus dan setelah dipelajari lagi lebih dalam melihat dari Al-Qur'an dan hadist akhirnya tau hijab yang sesuai syariat Islam. menggunakan hijab di rumah juga tidak hanya di sekolah saja dan model hijab yang digunakan saat berada di rumah dan sekolah sama. Teman bermain di sekolah tidak sama bentuk hijab yang dipakai tetapi saat di rumah sama seperti yang dipakai. Orang tua mewaibkan menggunakan hijab. Sudah mulai memotivasi kepada temen-temen sedikit demi sedikit yang belum menggunakan hijab agar mereka berhijab. Menyukai tokoh hijab ustadzah Oki Setiana Dewi karena hijabnya syar'i, dan cantik. Selain itu juga tetap terlihat anggun."

\section{Kesimpulan}

Dalam kajian ini melalui beberapa institusi pendidikan tingkat menengah atas seperti SMK Taruna Satria Pekanbaru, SMA Teknologi Pekanbaru, MA Darul Hikmah, dan SMK IT Al-Izhar. Dari beberapa koersioner yang telah penulis ajukan kepada para siswi yang berjumlah 23 orang mereka menyukai model hijab yang simple dan syar'i. alasannya karena lebih mudah dan nyaman saat digunakan. Mereka mengetahui model hijab seperti itu dari teman dan internet. Tokoh hijab yang paling banyak disukai adalah Nissa Sabyan karena ia terlihat simple walaupun model hijab yang digunakan sangat sederhana.

Kajian tersebut menunjukkan bahwa para siswi yang bersekolah dalam sekolah umum dengan bersekolah di sekolah yang dalam menggunakan hijab. Serta dalam menggunakan berhijab sangatlah berbeda. Dalam peranan pihak sekolah juga berbeda antara sekolah umum dengan sekolah berbasis Islam. Mulai dari segi peraturan hingga cara mendidik siswi untuk menggunakan hijab. Terlihat perbedaan antara sekolah yang berbasis sekolah umum dengan sekolah yang berbasis islam.

\section{Daftar Pustaka}

A Van Zoest. (1993). Semiotika : Tentang Tanda, Cara Kerjanya Dan Apa Yang Kita Lakukan Dengannya. Jakarta : Yayasan Sumber Agung.

Anisa Nurkhayati. (2015). Pengaruh Motivasi Memakai Hijab Terhadap Perilaku Sosial Siswi Smk Annuroniyah Sulang Rembang. Purwokerto: IAIN Purwokerto.

Bakri. (2019). Guru Akidah Akhlak. Pekanbaru: PPMA Darul Hikmah. Wawancara Pada 16 Januari 2019

Christomy. (2002). (Ed). Indonesia : Tanda Yang Retak. Jakarta : Wedatama Widya Sastra. Penerjemah Ibrahim. 
Dheajeng Thalita Riano. (2017). Buka-Tutup Hijab Di Kalangan Remaja (Studi Tentang Tindakan Sosial Pada Siswi Sma Dan Smk Di Surabaya). Surabaya: Universitas Airlangga

Dilla Annisa. (2019). Siswi Kelas XII Jurusan IPS. Pekanbaru: PPMA Darul Hikmah. Wawancara Pada 16 Januari 2019

Elisabeth Raleigh. (2004). Penelitian Hijab Dan Kebudayaan Populer Di Indonesia: Pengaruh Dan Persepsi.

Http://Inlislite.Uinsuska.Ac.Id/Uploaded_Files/Temporary/Digitalcollection/Yzhlzjj mnddkotkzztvizdblnziymmm4m2fhnduzywqxnde0nzy0yq==.Pdf. Diakses Tanggal 15 Januari 2019.

Http://Www.Alkhoirot.Net/2011/10/Pondok-Pesantren-Darul-Hikmah-Ppdh.Html, Diakses Tanggal 15 Januari 2019.

J Baudrillard. (1970). The Consumer Society: Myths And Structures (Published In Association With Theory, Culture E Society). London: Sage Publications.

J Baudrillard. (1983). Simulations.Translated By Paul Foss, Paul Patton And Phillip Beitchman. Cambridge: Cambridge University Press.

Khairun Nisa \& Rudianto. (2017). Trend Fashion Hijab Terhadap Konsep Diri Hijabers Komunitas Hijab Medan. Sumatera Utara: Jurnal Interaksi.

Maya Jumiati Yetri. (2013). Upaya Guru Meningkatkan Minat Belajar Santri Pada Mata Pelajaran Ekonomi Di Madrasah Aliyah Darel Hikmah Pekanbaru. Pekanbaru: Skripsi UIN Suska Riau

M Barnard. (2011). Fashion Sebagai Komunikasi. Penterjemah Idi Subandy Ibrahim. Yogyakarta : Jalasutra.

Muhammad Kholid Fathoni. (2005). Pendidikan Islam Dan Pendidikan Nasional, Paradigma Baru. Jakarta: Departemen Agama RI.

Piliang. (2011). Dunia Yang Dilipat, Tamasya Melampaui Batas-Batas Kebudayaan. Edisi Tiga. Bandung : Matahari.

S Willis Sofyan. (1994). Probleman Remaja Dan Pemecahannya. (Bandung: Aksara.

Shinta Nur Latifah Uswa. (2017). Hubungan Antara Kesadaran Menggunakan Hijab Dengan Perilaku Beragama Siswi Muslimah SMA Negeri 1 Sigaluh Kabupaten Banjarnegara. Purwokerto: Iain Purwokerto.

Tourmalina Tri Nugrahenny. (2016). Menyingkap Mekanisme Tanda Di Balik Hiperrealitas Tren Hijab: Analisis Semiotika Pada Fenomena Tren Hijab. Jakarta: Jurnal Komunikasi Indonesia Volume V, Nomor 1.

Ummi Hani. (2016). Pengaruh Motivasi Memakai Hijab Terhadap Perilaku Sosial Siswi Smk Annuroniyah Sulang Rembang. Semarang: UIN Walisongo 
Yuswohadi \& Gani. (2015). Marketing To The Middle Class Muslimah. Jakarta : PT. Gramedia Pustaka Utama.

8 Wajah Kelas Menengah. Jakarta: Pt Gramedia Pustaka Utama.

Zakiah Daradjat. (1999). Remaja Harapan Dan Tantangan. Jakata: CV. Ruhama.

\section{Narasumber Wawancara}

Bakri, guru akidah akhlak di PPMA Darul Hikmah, Pekanbaru

Dilla Annisa, siswi kelas XII Jurusan IPS: PPMA Darul Hikmah, Pekanbaru

Muhammad Syaifudin, guru Fikih di SMK IT Al-Izhar Pekanbaru

Putri, siswi kelas XII IPS SMA Teknologi Pekanbaru

Rada, siswi kelas XII Perbankan Syariah SMK IT Al-Izhar Pekanbaru

Safitri Zulyani, siswi kelas XII Jurusan Teknik Komputer Jaringan SMK Taruna

Satria Pekanbaru

Salahudin, guru Agama Islam di SMA Teknologi Pekanbaru

Zulkifli, guru Agama Islam di PPMA Darul Hikmah, Pekanbaru 